\title{
HUBUNGAN PAPARAN ASAP ROKOK DENGAN KEJADIAN \\ ISPA PADA BALITA DI WILAYAH KERJA PUSKESMAS \\ BANDAR AGUNG KECAMATAN TERUSAN NUNYAI KABUPATEN LAMPUNG TENGAH
}

\author{
Muhamad Kurniawan ${ }^{1}$, Wahid Tri Wahyudi ${ }^{2}$, M. Arifki Zainaro ${ }^{3^{*}}$ \\ ${ }^{1}$ Program Studi Keperawatan Universitas Malahayati \\ 2,3Dosen Keperawatan Universitas Malahayati \\ Email Korespondensi: m.arifkiz@yahoo.com
}

\section{ABSTRAK : THE CORRELATION OF CIGARETTE SMOKE EXPOSURE WITH URI CASE ON TODDLERS AT THE WORKING AREA OF BANDAR AGUNG HEALTH CENTRE TERUSAN NUNYAI SUBDISTRICT CENTRAL LAMPUNG REGENCY}

Introduction: URI or pneumonia is the disease most often suffered by toddlers, as many as $78 \%$ of toddlers come to visit health services with URI. Based on basic health research in 2018 it is known that the prevalence of URI according to Nakes diagnosis reaches 4.4\%. Bandar Agung health centre is the working area of health centres with the highest URI cases in central Lampung regency as many as 2141 cases. Smoking habits of parents in the house make toddlers as passive smokers who are always exposed to cigarette smoke. Homes where parents have the habit of smoking are likely to increase the incidence of URI.

Purpose: to know the correlation of cigarette smoke exposure with URI case on toddlers at the working area of Bandar Agung health centre Terusan Nunyai subdistrict Central Lampung regency year of 2019.

Method: Quantitative research type, by using cross sectional approach. The population in this research was all mothers who had toddlers and visited to Bandar Agung Health Centre Terusan Nunyai subdistrict Central Lampung regency as many 135 people. 101 sample respondents. Collecting data technique was by using questionnaire. Statistical test was by using chi square.

Result: There was the correlation of cigarette smoke exposure with URI case on toddlers at the working area of Bandar Agung health centre Terusan Nunyai subdistrict Central Lampung regency year of 2019 ( $p$ value 0,001. OR 4.2)

Conclusion: There was the correlation of cigarette smoke exposure with URI case on toddlers. It is expected that the Bandar Agung Health Center to conduct health promotion to the community, especially the promotion of the dangers of cigarettes, the contents contained in cigarettes that can endanger health, the effects caused by cigarette smoke, the dangers of cigarettes for active and passive smokers, in this case more disadvantaged are passive smokers especially toddlers. Because toddlers with smoker family members have a greater frequency of ARI

Keywords : Cigarette Smoke Exposure, URI Incident.

\section{INTISARI : HUBUNGAN PAPARAN ASAP ROKOK DENGAN KEJADIAN ISPA PADA BALITA DI WILAYAH KERJA PUSKESMAS BANDAR AGUNG KECAMATAN TERUSAN NUNYAI KABUPATEN LAMPUNG TENGAH}

Pendahuluan :ISPA atau pneumonia merupakan penyakit yang paling sering diderita oleh balita yaitu sebanyak $78 \%$ balita datang berkunjung ke pelayanan kesehatan dengan kejadian ISPA. Berdasarkan hasil Riskesdas 2018 diketahui 
bahwa prevalensi ISPA menurut diagnosa Nakes mencapai 4,4\%.Puskesmas Bandar agung merupakan wilayah kerja Puskesmas dengan kasus ISPA tertinggi di Kabupaten Lampung Tengah yaitu sebanyak 2.141 kasus. Kebiasaan merokok orang tua di dalam rumah menjadikan balita sebagai perokok pasif yang selalu terpapar asap rokok. Rumah yang orang tuanya mempunyai kebiasaan merokok berpeluang meningkatkan kejadian ISPA.

Tujuan: Untuk mengetahui hubungan paparan asap rokok dengan kejadian ISPA pada balita di Wilayah Kerja Puskesmas Bandar Agung Kecamatan Terusan Nunyai Kabupaten Lampung Tengah Tahun 2019.

Metode: Jenis penelitian kuantitatif, menggunakan pendekatan cross sectional. Populasi pada penelitian ini adalah seluruh ibu yang memiliki balita dan berkunjung ke Puskesmas Bandar Agung Kecamatan Terusan Nunyai Kabupaten Lampung Tengah berjumlah 135 orang. Sampel 101 responden. Tehnik pengumpulan data dilakukan dengan menggunakan kuesioner. Uji statistik yang digunakan adalah uji Chi Square.

Hasil: Ada hubungan paparan asap rokok dengan kejadian ISPA pada balita di Wilayah Kerja Puskesmas Bandar Agung Kecamatan Terusan Nunyai Kabupaten Lampung Tengah Tahun 2019 (p value 0,001. OR 4,2).

Kesimpulan: Ada hubungan paparan asap rokok dengan kejadian ISPA pada balita( $p$ value 0,001. OR 4,2). Diharapkan kepada pihak Puskesmas Bandar Agung untuk melakukan promosi kesehatan pada masyarakat khususnya promosi tentang bahaya rokok, kandungan-kandungan yang terdapat pada rokok yang dapat membahayakan kesehatan, efek yang ditimbulkan oleh asap rokok, bahaya rokok bagi perokok aktif maupun pasi, dalam hal ini yang lebih dirugikan adalah perokok pasif teruatama balita. Sebab, balita dengan anggota keluarga perokok mempunyai frekuensi terserang ISPA lebih besar

\section{Kata Kunci :Paparan Asap Rokok,Kejadian ISPA}

\section{PENDAHULUAN}

Data dari World Health Organization (WHO) menunjukkan angka kematian pada balita di dunia pada tahun 2013 sebesar 45,6 per 1.000 kelahiran hidup dan 15\% diantaranya disebabkan oleh ISPA. Menurut data yang diperoleh dari WHO pada tahun 2012, ISPA atau pneumonia merupakan penyakit yang paling sering diderita oleh balita yaitu sebanyak $78 \%$ balita datang berkunjung ke pelayanan kesehatan dengan kejadian ISPA. Setiap tahun, jumlah balita yang dirawat di rumah sakit dengan kejadian ISPA sebesar 12 juta (Tazinya et al, 2018). Insiden ISPA pada balita di negara berkembang diperkirakan 0,29 anak setiap tahun dan di negara maju sebanyak 0,05 anak setiap tahun. Penyebab kematian akibat ISPA di negara berkembang lebih tinggi dibandingkan negara maju yaitu sebesar 10-50 kali (Ramani et al, 2016).

TargetSustainable Development Goals (SDGs) 2030 berkaitan dengan program ISPA adalah menurunkan angka kematian Pneumonia balita (dari 44 menjadi 32 per 1000 kelahiran hidup). Berdasarkan hasil Riskesdas 2018 diketahui bahwa prevalensi ISPA menurut diagnosa Nakes mencapai 4,4\%. Namun berdasarkan gejala dan diagnosa Nakes prevalensinya mencapai 9.3\%, lebih rendah dibandingkan dengan tahun 2013 yang mencapai 25,0\% (Riskesdas, 2018).

Berdasarkan profil kesehatan Provinsi Lampung diketahui bahwa infeksi saluran napas atas menduduki posisi pertama dari sepuluh besar penyakit di Provinsi Lampung dengan 
prevalensi 19,62\%, disusul dengan Common Cold $(17,7 \%)$ dan hiperensi (16,19\%) (Dinkes Provinsi Lampung, 2016).

Penyakit infeksi saluran napas atas menurut data dinas kesehatan Lampung Tengah adalah penyakit yang masuk ke dalam sepuluh besar penyakit terbanyak dari seluruh puskesmas di Lampung Tengah yang termasuk pasien lama dan pasien baru pada tahun 2017, dan Puskesmas Bandar agung merupakan wilayah kerja Puskesmas dengan kasus ISPA tertinggi di Kabupaten Lampung Tengah yaitu sebanyak 2.141 kasus, sedangkan di Puskesmas Bandar Jaya yaitu sebanyak 1.745 kasus (Profil Kesehatan Lampung Tengah, 2017).

Penyebab umum infeksi saluran napas atas adalah virus dan bakteri. Meskipun begitu ada beberapa faktor presdisposisi yang dapat menyebabkan terjadinya penyakit faringitis, antara lain musim, cuaca/temperatur, debu, polusi, paparan asap rokok, pemakaian AC, anemia, avitaminosis A, alergi, hypothyroid, diabetes, merokok (Mulder, 2009).

Perokok pasif merupakan seseorang yang menghirup asap rokok dari perokok aktif. Paparan asap rokok dapat menyebabkan penyakit serius hingga kematian. Dampak dari asap rokok menjadi pembahasan serius oleh para ilmuwan. Perokok pasif dapat terkena risiko penyakit yang sama dengan perokok aktif, termasuk penyakit kardiovaskular, kanker paru-paru, dan penyakit pernapasan, kandungan tar dalam rokok memicu terjadinya iritasi paruparu dan kanker. Dalam tubuh perokok pasif, tar akan terkonsentrasi tiga kali lipat dibandingkan dalam tubuh perokok aktif (Depkes RI, 2009).

Kebiasaan merokok orang tua di dalam rumah menjadikan balita sebagai perokok pasif yang selalu terpapar asap rokok. Rumah yang orang tuanya mempunyai kebiasaan merokok berpeluang meningkatkan kejadian ISPA sebesar 7,83 kali dibandingkan dengan rumah balita yang orang tuanya tidak merokok di dalam rumah (Rahmayatul, 2013).

Berdasarkan pernyataan tersebut diketahui bahwa asap rokok dan merokok merupakan pemicu ISPA. Sementara itu konsumsi rokok meningkat secara pesat dari tahun ke tahun, Indonesia menduduki peringkat ketiga perokok terbesar di dunia pada tahun 2008 setelah China dan India (WHO, 2008). Prevalensi penduduk usia dewasa yang merokok setiap hari di Indonesia sebesar 29\% yang menempati urutan pertama se-Asia Tenggara. Pada tahun 2011, Indonesia memiliki jumlah perokok aktif terbanyak dengan prevalensi perokok laki-laki sebesar $67 \%$ (57,6 juta) dan prevalensi perokok wanita sebesar 2,7\% (2,3 juta). Pada tahun 2011, prevalensi merokok lebih tinggi di daerah pedesaan $(37,7 \%)$ dibandingkan dengan daerah perkotaan (31,9\%) (GATS, 2011). Hasil Riskesdas tahun 2013 menunjukkan jumlah perokok di Provinsi Lampung mencapai 22.0\%, dan untuk Kabupaten Lampung Tengah sendiri mencapai $14.3 \%$.

Berdasarkan data Perilaku Hidup Bersih dan Sehat (PHBS) di Kabupaten Lampung Tengah, dari 194.961 rumah tangga yang ada, telah dilakukan pemeriksaan PHBS sebesar 48\%. Dari rumah tangga yang diperiksa tersebut, 92,49\% berada pada tatanan sehat utama dan paripurna, ini artinya perilaku hidup bersih dan sehat masyarakat sudah tergolong baik. Namun ada salah satu indikator dari PHBS yang capaiannya tergolong masih sangat rendah yaitu keluarga bebas asap rokok, ini berarti masyarakat yang ada di Kabupaten Lampung Tengah masih banyak yang terpapar asap rokok (Dinas Kesehatan Kabupaten Lampung Tengah, 2018). Menurut data tersebut, dari 165.776 rumah tangga yang diperiksa, 
ada 46,19\% berstatus perokok. Perilaku merokok baik di dalam maupun di luar rumah dengan persentase tertinggi yaitu di wilayah kerja Puskesmas Bandar Agung dari 4.795 rumah tangga yang diperiksa hanya $31,90 \%$ keluarga yang bebas asap rokok, itu artinya terdapat $69,10 \%$ rumah tangga yang memiliki minimal seorang perokok di dalamnya (Dinas Kesehatan Kabupaten Lampung Tengah, 2018).

Hasil penelitian Wardani (2016) menunjukkan ada hubungan dengan kekuatan hubungan sedang antara paparan asap rokok dengan kejadian ISPA pada Balita di Desa Pucung Rejo Kabupaten Magelang Tahun 2014. Dengan hasil $\mathrm{p}<0,07$, coeffisient contingency di dapati hasil 0,537 yang berarti bahwa kekuatan hubungan adalah sedang.

Berdasarkan hasil wawancara yang dilakukan terhadap 10 anggota keluarga balita penderita ISPA diperoleh informasi bahwa 8 diantaranya orang tuanya adalah perokok. Oleh karena itu peneliti tertarik untuk meneliti hubungan paparan asap rokok dengan kejadian ISPA pada balita di Wilayah Kerja Puskesmas Bandar Agung Kecamatan Terusan Nunyai Kabupaten Lampung Tengah Tahun 2019.

Tujuan penelitian ini adalah diketahui hubungan paparan asap rokok dengan kejadian ISPA pada balita di Wilayah Kerja Puskesmas Bandar Agung Kecamatan Terusan Nunyai Kabupaten Lampung Tengah Tahun 2019

\section{METODOLOGI PENELITIAN}

Penelitian ini menggunakan rancangan penelitian cross sectional. Populasi pada penelitian ini adalah seluruh ibu yang memiliki balita dengan ISPA dan berkunjung ke Puskesmas Bandar Agung Kecamatan Terusan Nunyai Kabupaten Lampung Tengah tahun 2018 berjumlah 1620 orang dengan rata-rata kunjungan balita tiap bulan sebanyak 135 orang, dengan sampel sejumlah 101.Pengumpulan data menggunakan kuesioner dan observais lembar rekam medis. Uji statistik yang digunakan adalah uji Chi Squaremenggunakan aplikasi SPSS versi 25.0 dan telah dilakukan uji etik dengan nomor No. 544/EC/KEP-UNIMAL/VIII/2019.

Pengolahan data menggunakan aplikasi SPSS versi 20.

\section{HASIL PENELITIAN}

\section{Karakteristik Responden}

Tabel 1. Distribusi Frekuensi Responden Berdasarkan Jenis

Kelamin Balita, Usia Ibu, Pekerjaan Ibu

\begin{tabular}{lcc}
\hline \multicolumn{1}{c}{$\begin{array}{c}\text { Karakteristik } \\
\text { Responden }\end{array}$} & Jumlah & Persentase \\
\cline { 1 - 1 } $\begin{array}{l}\text { Jenis kelamin: } \\
\text { Laki-laki }\end{array}$ & & \\
Perempuan & 58 & 57.4 \\
\cline { 1 - 2 } $\begin{array}{l}\text { Usia Ibu: } \\
\text { Reproduksi } \\
\text { Berisiko }\end{array}$ & 18 & 17.8 \\
Reproduksi Sehat & 83 & 82.2 \\
\hline Pekerjaan Ibu: & & \\
lbu Rumah tangga & 65 & 64.4 \\
Pegawai Swasta & 8 & 7.9 \\
Pegawai Negeri & 4 & 4.0 \\
Wiraswasta & 12 & 11.9 \\
Tani & 12 & 11.9 \\
\hline \multicolumn{1}{c}{ Jumlah } & 101 & 100,0
\end{tabular}

Berdasarkan tabel 1 diketahui bahwa sebagian besar balita berjenis kelamin laki-laki yaitu sebanyak 58 responden $(57,4 \%)$. sebagian besar ibu dalam rentang usia reproduksi sehat yaitu sebanyak 83 responden $(82,2 \%)$, ibu tidak bekerja (Ibu rumah tangga) yaitu sebanyak 65 responden $(64,4 \%)$.

\section{Analisis Univariat}

Tabel 2.Distribusi Frekuensi

Responden Berdasarkan paparan asap rokok dan kejadian ISPA 


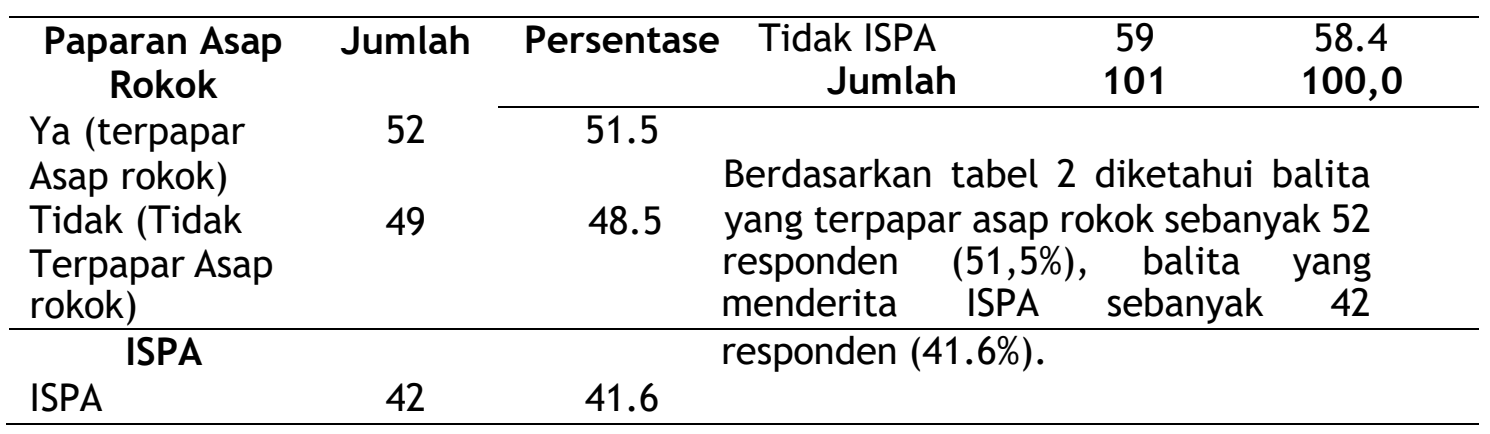

3. Analisis Bivariat

a. Hubungan Paparan Asap Rokok Dengan Kejadian Ispa Pada Balita

Tabel 3

Hubungan Paparan Asap Rokok Dengan Kejadian ISPA pada balita

\begin{tabular}{|c|c|c|c|c|c|c|c|}
\hline \multirow{3}{*}{$\begin{array}{c}\text { Paparan Asap } \\
\text { Rokok }\end{array}$} & \multicolumn{4}{|c|}{ Kejadian ISPA } & \multirow{3}{*}{ Total } & \multirow{3}{*}{$\begin{array}{c}P \\
\text { Value }\end{array}$} & \multirow{3}{*}{$\begin{array}{c}\text { OR } \\
\text { (Cl 95\%) }\end{array}$} \\
\hline & \multicolumn{2}{|c|}{ ISPA } & \multicolumn{2}{|c|}{ Tidak } & & & \\
\hline & $\mathrm{n}$ & $\%$ & $n$ & $\%$ & & & \\
\hline $\mathrm{Ya}$ & 30 & 57.7 & 22 & 42.3 & 52 & 0,001 & $4,2(1,8-$ \\
\hline Tidak & 12 & 24.5 & 37 & 75.5 & 49 & & $9,9)$ \\
\hline Total & 42 & 41.6 & 59 & 58.4 & 101 & & \\
\hline
\end{tabular}

Hasil penelitian didapatkan bahwa dari 52balita yang terpapar asap rokok, sebanyak 30 responden $(57,7 \%)$ menderita ISPA. Sedangkan dari49 balita yang tidak terpapar asap rokok, sebanyak 12 balita (24.5\%) menderita ISPA. Hasil uji chi square didapatkan nilai $p$ value 0,001 , artinya lebih kecil dibandingkan dengan nilai alpha $(0,001<0,05)$. Dengan demikian dapat disimpulkan secara statistik dengan derajat kepercayaan 95\%, diyakini terdapat hubungan paparan asap rokok dengan kejadian ISPA pada balita di Wilayah Kerja Puskesmas Bandar Agung Kecamatan Terusan Nunyai Kabupaten Lampung Tengah Tahun 2019. Sedangkan hasil uji OR diperoleh nilai 4,2 (Cl 95\% 1,8-9,9) artinya balita yang terpapar asap rokok berrisiko 4,2 kali lebih besar untuk menderita ISPA dibandingkan balita yang tidak terpapar asap rokok.

\section{PEMBAHASAN}

\section{Analisis Univariat}

a. Paparan Asap Rokok

Hasil penelitian ini sejalan dengan penelitian Wardani (2016) tentang
Hubungan Antara Paparan Asap Rokok Dengan Kejadian Infeksi Saluran Pernapasan Akut (ISPA) Pada Balita Di Desa Pucung Rejo Kabupaten Magelang yang menunjukkan sebagian besar balita di Desa Pucung Rejo mendapatkan paparan asap rokok dengan prosentase $81,0 \%$ atau 34 balita.

Berdasarkan teori yang peneliti dapatkan prosentase terjadinya penyakit ISPA pada balita salah satunya disebabkan karena paparan asap rokok yang berada di lingkungan disekitar bayi. Sebab, terdapat seorang perokok atau lebih dalam rumah akan memperbesar resiko anggota keluarga yang menderita sakit, seperti gangguan pernapasan, memperburuk asma dan memperberat penyakit angina pectoris serta dapat meningkatkan resiko untuk mendapat serangan ISPA khususnya pada balita. Anakanak yang orangtuanya merokok lebih mudah terkena penyakit 
saluran pernapasan seperti flu, asma, pneumonia dan penyakit saluran pernapsan lainnya. Gas berbahaya dalam asap rokok merangsang pembentukan lendir, debu dan bakteri yang tertumpuk tidak dapat dikeluarkan, menyebabkan bronchitis kronis, lumpuhnya serat elastin di jaringan paru yang mengakibatkan daya pompa paru berkurang, udara tertahan di paru-paru dan mengakibatkan pecahnya kantong udara.

Menurut penelitian dapat disimpulkan bahwa sebagian besar balita mendapatkan paparan asap rokok. Walaupun hanya menghabiskan sedikit batang rokok per hari jika dalam jangka waktu yang lama, zat-zat berbahaya tersebut akan tersimpan dan terakumulasi dalam tubuh yang menyebabkan berbagai penyakit. Karena dalam sebatang rokok mengandung nikotin, tar, sianida, benzene, amonia, karbon monoksida, cadmium dan zat berbahaya lainnya (Husaini, 2006 dalam Wardani, 2015).

\section{b. Kejadian ISPA}

Berdasarkan teori yang didapat olehpeneliti, ISPA adalah penyakit infeksiyang menyerang saluran pernapasanbagian atas maupun bagian bawahantara lain batuk pilek, sakit telinga (otitis media), bronkitis dan pneumoniadan berlangsung sampai 14 hari. Ada banyak factorpencetus terjadinya penyakit ISPApada balita, salah satu faktor pencetusnya adalah terdapatnya polusiudara dalam ruangan (paparan asaprokok) (Sujayanto, 2006).

ISPA dapat disebabkan oleh karena adanyapaparan dari virus maupun bakteri misalnyabakteridarigenusstreptoc occus, haemophylus, staphylococcu $s$, danpneumococcu, dan jenis virus influenza,parainfluena, dan rhinovirus. Selain dari virus, jamur dan bakteri, ISPA juga dapat disebabkankarena sering menghirup asap rokok, asapkendaraan bermotor, Bahan Bakar Minyakbiasanya minyak tanah dan, cairan ammoniumpada saat lahir (Utami, 2013).

Hasil penelitian ini sejalan dengan penelitian Milo (2015) tentang Hubungan Kebiasaan Merokok Di Dalam Rumah DenganKejadian Ispa Pada Anak Umur 1-5 Tahun Di Puskesmas Sario Kota Manado, yang menunjukkan 34 responden (66.7\%) mengalami ISPA ringan.

Menurut peneliti ISPA dapat disebabkan oleh karena adanya paparan dari virus maupun bakteri misalnya bakteri dari genus streptococcus, haemophylus, staphylococcus, dan pneumococcu, dan jenis virus influenza, parainfluena, dan rhinovirus. Selain dari virus, jamur dan bakteri, ISPA juga dapat disebabkan karena sering menghirup asap rokok, asap kendaraan bermotor, Bahan Bakar Minyak biasanya minyak tanah dan, cairan amonium pada saat lahir

\section{Analisa Bivariat}

Secara teori asap rokok tidak hanya berbahaya bagi perokoknya, tetapi jugaberbahaya bagi orang disekitarnya yangsecara tidak langsung menghisap(perokok pasif). Resiko asap rokokbagi perokok pasif dewasa dapatterkena kanker paru-paru, bayi yangdikandung oleh ibu perokok pasifberpotensi mempunyai 
kelainan, dananak-anak dari perokok lebih rentanterhadap infeksi saluran pernapasan(Wardani, 2015)

Klasifikasi ISPA munurutkelompok umur 2 bulan-5 tahun yaitupneumonia berat, yaitu adanya batukdan atau kesukaran bernafas disertaipenarikan dinding dada bagian bawahke dalam (chest indrawing), Pneumonia yaitu batuk dan atau kesukaranbernafas disertai nafas cepat denganbatas napas cepat pada anak usia 2bulan sampai kurang dari tahun 1 tahunadalah 50 kali atau lebih permenit dan40 kali atau lebih permenit, dan Batukbukan pneumonia yaitu penderita batukyang tidak disertai napas cepat dantidak ada tarikan dinding dada bagianbawah ke dalam. (Program P2 ISPA)Kandungan dari asap Sidestream lebih berbahaya daripada asapMainstream. Kandungan carcinogenicsyang ada padanya mencapai 4 (empat)kali lipat dari asap Mainstream.

Asap rokok dari orang tua atau penghuni rumah yang satu atap dengan balita merupakan bahan pencemaran dalam ruang tempat tinggal yang serius serta akan menambah resiko kesakitan dari bahan toksik pada anak-anak. Paparan yang terus-menerus akan menimbulkan gangguan pernafasanterutama memperberat timbulnya infeksi saluran pernafasanakut dan gangguan paru-paru pada saat dewasa. Semakin banyak rokok yang dihisap oleh keluarga semakin besar memberikan resiko terhadap kejadian ISPA, khususnya apabila merokok dilakukan oleh ibu bayi(Trisnawati dan Juwarni,2012).

Selain kebiasaan merokok di dalam rumah terdapat juga beberapa faktor yang dapat menyebabkan ISPA, antara lain, yaitu faktor lingkunganmeliputi: pencemaran udara dalam rumah (asap rokok dan asap hasilpembakaran bahan bakar untuk memasak dengan konsentrasi yang tinggi), kondisi rumah, ventilasi rumah dan kepadatan hunian(Astuti, 2012). Faktor-faktor tersebut juga erat hubungannya dengan peningkatan daya tahan tubuh sehingga dapat menyebabkan terjadinya ISPA, maka ada yang perokok berat tetapi terkena ISPA ringan dan adapun yang perokok berat tetapi terkena ISPA sedang. Oleh karena itu selain kebiasaan merokok perlu diperhatikan juga kondisi rumah, ventilasi rumah, dan kepadatan hunian.

Kebiasaan merokok di dalamrumah salah satu masalah kesehatanyang kian mengkhawatirkan dilndonesia adalah semakin banyaknyajumlah perokok yang berarti semakinbanyak penderita gangguan kesehatanakibat merokok ataupun menghirupasap rokok (bagi perokok pasif). Terdapat seorang perokok ataulebih dalam rumah akan memperbesarresiko anggota keluarga yang men-derita sakit, seperti gangguan pernapasan, memperburuk asma dan memperberat penyakit angina pectoris sertadapat meningkatkan resiko untuk mendapat serangan ISPA khususnya padabalita. Anakanak yang orangtuanyamerokok lebih mudah terkena penyakitsaluran pernapasan seperti flu, asma, pneumonia dan penyakit saluran pernapasan lainnya. Gas berbahaya dalamasap rokok merangsang pembentukanlendir, debu dan bakteri yang tertumpuk tidak dapat dikeluarkan, menyebabkan bronchitis kronis, lumpuhnyaserat elastin di jaringan paru yangmengakibatkan daya pompa paru berkurang, udara 
tertahan di paru-paru danmengakibatkan pecahnya kantong udara. (Widiawati dalam Kabar Priangan,2012)

Hasil penelitian ini sejalan dengan penelitian Wardhani dkk (2016) tentang Hubungan Antara Paparan Asap Rokok Dengan Kejadian Infeksi Saluran Pernapasan Akut (ISPA) Pada Balita Di Desa Pucung Rejo Kabupaten Magelang Tahun 2014, hasil penelitian menunjukkan ada hubungan dengan kekuatan hubungan sedang antara paparan asap rokok dengan kejadian ISPA pada Balita di Desa Pucung Rejo Kabupaten Magelang Tahun 2014. Dengan hasil $p<0,07$, coeffisient contingency di dapati hasil 0,537 yang berarti bahwa kekuatan hubungan adalah sedang.

Hasil penelitian juga menunjukkan terdapat 22 responden $(42,3 \%)$ yang orangtua ataupun anggotakeluarganya merokok di dalam rumahada yang tidak mengalami ISPA. Menurut penelitihaltersebut dikarenakan oleh beberapafaktor, seperti status gizinya baik dan mendapatkan imunisasi lengkap sehingga memiliki daya tahan tubuh yang baik dan tidak mudah terinfeksi, balita tidak berada didekat anggota keluarga yang sedangmerokok atau balita tersebut sedangtidak di rumah sehingga tidak terpaparlangsung oleh asap rokok.

Sedangkan pada 12 balita $(24,5 \%)$ dengan keluarga yangmerokok di luar rumah atau balita yangtidak ada paparan asap rokok, prosentase untuk balita terserang ISPAsangat kecil, tetapi tidak dipungkiribahwa hal tersebut tetap saja bisa terjadi. Kemungkinan yang menyebabkan balita tersebut terserang ISPAadalah faktor lingkungan yang kurangmendukung seperti polusi udara. Debumerupakan salah satu dari polusi udarapenyebab ISPA, sebab debu yang masuk dalam saluran pernafasan akanmembawa bakteri yang dapat menginfeksi saluran pernafasan sehinggaproduksi lendir meningkat menyebabkan debu dan bakteri yang menyertaiakan tertumpuk di saluran pernafasanyang nantinya akan menimbulkanperubahan anatomi saluran pernapasansehingga fungsi dari paru-paru berubahdan terjadi infeksi saluran pernapasanseperti ISPA. Danmasih banyak faktor lain yang dapatmejadi faktor resiko terjadinya ISPAselain dari faktor lingkungan.

Sehingga diharapkan pada masyarakat untuk tidak merokok terutama di sekitar balita, dan menghindari paparan asap rokok pada balita seperti mengganti pakaian dan mencuci tangan setelah merokok sebelum menyentuh balita.

\section{KESIMPULAN}

1. Balita yang terpapar asap rokok sebanyak 52 responden (51,5\%), sedangkan yang tidak terpapar asap rokok sebanyak 49 responden $(48,5 \%)$.

2. Balita yang menderita ISPA sebanyak 42 responden (41.6\%) dan yang tidak menderita ISPA sebanyak 59 responden (58.4\%).

3. Ada hubungan paparan asap rokok dengan kejadian ISPA pada balita di Wilayah Kerja Puskesmas Bandar Agung Kecamatan Terusan Nunyai Kabupaten Lampung 
Tengah Tahun 2019 ( $\mathrm{p}$ value 0,001 . OR 4,2).

\section{SARAN}

1. Diharapkan kepada pihak Puskesmas Bandar Agung untuk melakukan promosi kesehatan pada masyarakat khususnya promosi tentang bahaya rokok, kandungan-kandungan yang terdapat pada rokok yang dapat membahayakan kesehatan, efek yang ditimbulkan oleh asap rokok, bahaya rokok bagi perokok aktif maupun pasi, dalam hal ini yang lebih dirugikan adalah perokok pasif teruatama balita. Sebab, balita dengan anggota keluarga perokok mempunyai frekuensi terserang ISPA lebih besar

2. Diharapkan kepada masyarakat untuk tidak merokok terutama di sekitar balita, dan menghindari paparan asap rokok pada balita seperti mengganti pakaian dan mencuci tangan setelah merokok sebelum menyentuh balita.

3. Untuk itu disarankan kepada keluarga agar tidak merokok di dalam rumah ketika bersama anggota keluarga terlebih ada anak balita. Keluarga diharapkan mengetahui bahaya asap rokok terhadap kesehatan anggota keluarga.

\section{DAFTAR PUSTAKA}

Ahmad $\mathrm{H}$ et al., 2018. The DeterminantFactors of Acute Respiratory Infections(ARI) among Housewives in AllakuangVillage, South Sulawesi, Indonesia. The2nd International Meeting of PublicHealth 2016. p: 503-504

Aprilioza, Almer. 2016. Hubungan kebiasaan merokok pada orang tua di rumah dengan kejadian pneumonia pada balita di Wilayah Kerja Puskesmas
Plered. Jurnal Fakultas Kedokteran Universitas Islam Bandung

Asih, Y. (2017). Hubungan Status Gizi danPaparan Rokok dengan Kejadian ISPApada Balita di Sukaraja BandarLampung. Jurnal Kesehatan Metro SaiWawai Volume Vii No. 1 , 4147

Basuki PP, Febriani H 2017. HubunganAntara Kriteria Perokok denganKejadian Infeksi Saluran PernapasanAkut (ISPA) pada Balita di WilayahKerjaKecamatanPramba nanYogyakarta. 679-687

Dita Maharani, F. F. (2017). Profil Balita Penderita Infeksi Saluran Nafas Akut Atas di Poliklinik Anak RSUP DR. M. Djamil Padang Tahun 2012-2013 . Jurnal Kesehatan Andalas Vol 6, no 1,152-157.

Efni Yulia, Rizanda Machmud, dan Pertiwi Dian (2016). Faktor Risiko yang Berhubungan dengan Kejadian Pneumonia pada Balita di Kelurahan Air Tawar Barat Padang. Jurnal Kesehatan Andalas Vol 5, No 2

Hartono R dan Dwi Rahmawati. 2016. ISPA gangguan pernafasan pada anak. Yogyakarta : Nuha Medika Imaniyah Ervi, Irma Jayatmi (2019). Determinan Kejadian Infeksi Saluran Pernapasan Akut (ISPA) pada Balita. Jurnal Ilmiah Kebidanan Indonesia. Vol 9 No

Kementrian Kesehatan RI. (2015). Pusat Data dan Informasi Profil Kesehatan Indonesia 2014. Jakarta : Kemenkes RI

Konsensus 2017. Pertemuan Ahli InfeksiSaluranPernafasanAtas.ht tps://issuu.com/dhentyf.sahar a/docs/buku_saku_fix.Diaksest anggal 25 Juni 2019

Mulder, AAH. (2009). Pharyngitis, tonsilitis, and laryngitis. MIMS Disease Review. 
Ramani, V K., J. Pattankar., S.K. Puttahonnappa. (2016). Acute Respiratory Infections Among Under-Five Age Group Children at Urban Slums of Gulbarga City : A Longitudinal Study. Journal of Clinical and Diagnostic Research, 10(5), 8-13

Rahmawati. 2017. Hubungan antara perilaku merokok pada orang tua dengan kejadian infeksi saluran pernapasan akut (ISPA) pada anak balita di Puskesmas Porong. Jurnal Fakultas IImu Keolahragaan Univesitas Negeri Malang

Rasmaliah. 2017. Infeksi Saluran Pernafasan Akut (ISPA) Dan Penanggulangannya. Jurnal. Fakultas Kesehatan Masyarakat Universtias Sumatera Utara.

Tazinya, A A., G E. Halle-Ekane., L T. Mbuagbaw, et al. (2018). Risk Factors for Acute Respiratory Infections in Children Under Five Years Attending the Bamenda Regional Hospital in Cameroon. 18(7), 1-8

Trisnawati, Y. T., \& Juwarni, J. (2013). Hubungan Perilaku Merokok Orang Tua Dengan Kejadian ISPA Pada Balita Di Wilayah Kerja Puskesmas Rembang Kabupaten Purbalingga 2012. Kesmas Indonesia, 6(01), 35-42.

Wahyuningsih S 2017. Infeksi SaluranPernafasan Akut (ISPA) pada Balita diWilayah Pesisir Desa Kore KecamatanSanggar Kabupaten Bima. HigineJurnal Kesehatan Masyarakat. 3(2): 9899

Wardani, N. K., Winarsih, S., \& Sukini, T. (2015). Hubungan Antara Paparan Asap Rokok Dengan Kejadian Infeksi Saluran Pernapasan Akut (ISPA) Pada Balita Di Desa Pucung Rejo Kabupaten Magelang. Jurnal Kebidanan, 5(10), 30-37.
Widoyono. (2011). Penyakit Tropis: Epidemiologi, Penularan, Pencegahan dan. Pemberantasannya. Jakarta: Penerbit Erlangga

World Health Organization. (2008). WHO Report On The Global Tobacco Epidemic 2008. Geneva : WHO 